\title{
Mechanical and Electrical Properties of Nano Al-Matrix Composites Reinforced with SiC and Prepared by Powder Metallurgy
}

\author{
Mahmoud F. Zawrah ${ }^{1}$ (D), Wafaa M. El-Meligy ${ }^{2}$, Heba H. A. Saudi ${ }^{3}$ (D), Safae Ramadan ${ }^{4}$, Mohammed A. \\ Taha 5 (iD \\ 1 Refractories; Ceramics and Building Materials Department; National Research Centre; 2622-Dokki; Cairo; Egypt \\ 2 Department of Physics; Faculty of Science; Al-Azhar University (Girls' Branch); Nasr City, Egypt; \\ wafaamohamed@yahoo.com (W.M.E.M.); heba_saudi@hotmail.com (H.A.S.); \\ 3 Solid State Physics Department; National Research Centre; 12622-Dokki; Cairo; Egypt; sramadan@gmail.com (S.R.); \\ mtahanrc@gmail.com (M.A.T.); \\ * Correspondence: mzawrah@hotmail.com (M.F.Z.);
}

Scopus Author ID 6604055746

Received: 22.04.2021; Revised: 28.05.2021; Accepted: 30.05.2021; Published: 18.06.2021

Abstract: Nano Al-matrix composites reinforced with $\mathrm{SiC}$ were prepared by powder metallurgy process. The percentages of added $\mathrm{SiC}$ were varied between $0,2,4,6$, and $8 \mathrm{wt}$. \%. The starting powders were milled in high-energy ball mill for $10 \mathrm{hrs}$ to convert into nanopowders; then compacted and sintered for $1 \mathrm{~h}$ in an argon atmosphere at 400,500 , and $570^{\circ} \mathrm{C}$. X-ray technique and transmission electronmicroscope were utilized to examine the prepared powders, while scanning electron-microscope was utilized to test the sintered composites. The relative density, apparent porosity, electrical conductivity, and mechanical properties (microhardness, elastic moduli, and compressive strength) of sintered composites were studied. The results showed no sign for phase changes after milling, and the SiC reinforcement was uniformly distributed in the matrix. The relative density and electrical conductivity were decreased with increasing $\mathrm{SiC}$ content, while the apparent porosity was increased. It is also found that the mechanical properties were improved with increasing $\mathrm{SiC}$ content. Also, all properties were improved with increasing sintering temperature. The hardness, compressive strength, bulk modulus of Al-8wt.\% SiC composite sintered at $570^{\circ} \mathrm{C}$ were $885.4 \mathrm{MPa}, 276.2 \mathrm{MPa}$, and $135.9 \mathrm{GPa}$, respectively.

Keywords: Al-SiC composites; sintering; physical properties; mechanical-properties; electrical conductivity.

(C) 2021 by the authors. This article is an open-access article distributed under the terms and conditions of the Creative Commons Attribution (CC BY) license (https://creativecommons.org/licenses/by/4.0/).

\section{Introduction}

No doubt, the metal-matrix nanocomposites reinforced with ceramic particles have excellent properties like high thermal conductivity, high young's modulus, high ultimate strength, low density, high-temperature resistance. So, they can be applied for many engineering applications in the aerospace energy, defense, and automobile industry. The most interesting metal matrix composites are the Al base nanocomposites. They can be reinforced by different types of reinforcements in the form of particles, whiskers, or short-fibers [1-4]. The addition of ceramic particles to $\mathrm{Al}$ can improve the mechanical properties, especially the hardness and strength [5]. Many types of ceramics have been utilized to improve the properties of $\mathrm{Al}$ base nanocomposites; including $\mathrm{Al}_{2} \mathrm{O}_{3}$ [6,7], $\mathrm{ZrO}_{2}$ [8], $\mathrm{ZrC}$ [9], $\mathrm{TiB}_{2}$ [10], $\mathrm{B} 4 \mathrm{C}$ [2], and $\mathrm{SiC}[5,11]$. Among these ceramics, $\mathrm{SiC}$ ceramic can be used as an excellent reinforcement for 
$\mathrm{Al}$ base nanocomposites due to its high microhardness (about $25 \mathrm{GPa}$ ), good wear resistance, and appropriate electrical and thermal conductivity. The addition of $\mathrm{SiC}$ leads to a significant improvement of the mechanical properties of the composite, i.e., microhardness, strength, elastic modulus, and wear resistance without a severe decrease in the electrical and thermal characteristics of the nanocomposites $[1,12,13]$. The ideal microstructure of Al-SiC composite should include homogenously dispersed $\mathrm{SiC}$ nanoparticles in fine-grains $\mathrm{Al}$ matrix. This leads to improving the physico-mechanical properties of the nanocomposite; their values increase with increasing the percentages of added $\mathrm{SiC}$ [12,14,15]. Friction stir [7], stir casting [16], and mechanical alloying (MA) [17-19] are the most common processes for the production of Al$\mathrm{SiC}$ nanocomposites. Mechanical alloying is one of the most interesting tools used to produce $\mathrm{Al}-\mathrm{SiC}$ nanocomposites with significant mechanical properties. This is due to it can produce composites with uniform distribution of $\mathrm{SiC}$ particles between $\mathrm{Al}$ matrix grains. Throughout the milling process, the $\mathrm{SiC}$ particles can well-disperse in the matrix, a repeated cold-welding has occurred, and finally, the fracturing is happened [1,20]. This process depends on many parameters, including the particle size of starting powders, types of matrix and reinforcement powders, milling time, the weight of ball-to-powder ratio, milling speed, and atmosphere of milling $[21,22]$. In this study, the effect of $\mathrm{SiC}$ contents on phase composition, sinterability, physical, mechanical, and electrical properties of Al-matrix nanocomposites is the main goal. In detail, throughout this work, the influence of the milling process on the powder particle size, morphology, crystal size, and dislocation density are also investigated. For the sintered composites, the microstructure, density, porosity, microhardness, compressive, yield, elastic moduli, fracture strain, and electrical conductivity are studied in relationship to $\mathrm{SiC}$ contents and sintering temperatures

\section{Materials and Methods}

\subsection{Materials.}

Al powder having $99.9 \%$ purity and average particle size of $45 \mu \mathrm{m}$, as well as $\mathrm{SiC}$ having 99.8 purity and average particle size of $60 \mathrm{~nm}$, were used as starting powders to produce Al-SiC nanocomposites.

\subsection{Experimental methods.}

Various weight percentages of $\mathrm{SiC}$, i.e., $0.0,2,4,6$, and $8 \mathrm{wt} \%$, were utilized to produce designed Al-SiC composites (AS0, AS2, AS4, AS6, and AS8). The mixed powders have been milled for $10 \mathrm{hrs}$ using a planetary ball-mill type MTI/SFM-1(QM-3SP2) in the presence of $1 \mathrm{wt} .-\%$ stearic acid as a processing-controlling agent to avoid agglomeration of the powders through milling. The powder mixtures were milled using $\mathrm{Al}_{2} \mathrm{O}_{3}$-balls with a diameter of $20 \mathrm{~mm}$, with $500 \mathrm{rpm}$ rotating speed and ball to powder ratio of 20:1. To recognize the phase composition, crystal size, lattice strain, dislocation density, and particle size of milled powders, X-ray instrument type "Philips PW 1373 and transmission electron-microscopy (TEM) kind "JEOL JEM-1230" were employed. The crystal size (D) of the milled powders was calculated using Scherer eqn. (1) [23].

$$
\mathrm{D}=\frac{0.9 \lambda}{\mathrm{B} \cos \theta}
$$

since $\lambda=1.540591 \mathrm{~A}^{\circ}, \beta$ is the full width at half maximum and $\theta$ is angle (in radians).

The dislocation density $(\delta)$ was estimated by eqn. (2) [24]. 


$$
\delta=\frac{1}{\mathrm{D}^{2}}
$$

The lattice strain (e) was also estimated by the following eqn. (3) [25].

$$
\varepsilon=\frac{B}{4 \tan \theta}
$$

The prepared powders were cold-compacted at $20 \mathrm{MPa}$ into small pellets with the desired size having $16 \mathrm{~mm}$ in diameter and $5 \mathrm{~mm}$ in height. The pressed specimens were sintered for $1 \mathrm{~h}$ at 400,500 , and $570^{\circ} \mathrm{C}$ in an inert atmosphere with heat-rating $7{ }^{\circ} \mathrm{C} / \mathrm{min}$. The physical properties in terms of relative density and apparent-porosity of sintered composites were assessed using Archimedes' process permitting to ASTM-B962-13. The theoretical density of Al-SiC composites was considered according to the rule of mixtures, considering the full dense values of $\mathrm{Al}$ and $\mathrm{Al}_{2} \mathrm{O}_{3}$ are 2.7 and $3.95 \mathrm{~g} / \mathrm{cm}^{3}$, respectively. Then, the relative density of sintered pellets was estimated using the bulk- and theoretical-density. Vickers microhardness of sintered composites was determined following ASTM-B933-09 using load $1.961 \mathrm{~N}$ for 10 seconds. Vickers hardness was estimated by the mathematical expression no. 4, where $\mathrm{P}$ is the applied load and D is the diagonal of obtained shape after indentation [26,27].

$$
\mathrm{Hv}=1.854 \times \frac{\mathrm{P}}{\mathrm{D}^{2}} \ldots
$$

The compressive strength of sintered composites was determined according to ASTM E9. Also, the yield strength, compressive strength, strengthening efficiency (R), and fracture strain were calculated from the stress-strain curve. The longitudinal $\left(\mathrm{V}_{\mathrm{L}}\right)$ and shear $\left(\mathrm{V}_{\mathrm{S}}\right)$ ultrasonic wave-velocities spread in the sintered composites were estimated by pulse-echo technique MATEC-Model-MBS8000-DSP (ultrasonic digital-signal process) having $5 \mathrm{MHz}$ resonance. According to the following equations, the quantities of $\lambda$ and $\mu$ (Lame's constants) were calculated from VL and VS ultrasonic velocities [28].

$$
\begin{gathered}
\lambda=\rho\left(V_{L}^{2}-2 V_{S}^{2}\right. \\
\mu=\rho V_{S}^{2}
\end{gathered}
$$

since $\rho$ is the bulk density of matter.

The quantities of elastic-moduli, i.e., longitudinal-modulus $(L)$, shear-modulus $(G)$,Young's-modulus $(E)$, bulk modulus $(B)$ and Poisson's ratio $(v)$ were estimated according to the following equations $[29,30]$.

$$
\begin{gathered}
L=\lambda+2 \mu \\
G=\mu \\
E=\mu \frac{3 \lambda+2 \mu}{\lambda+\mu} \\
B=\lambda+\frac{2}{3} \mu \\
v=\frac{\lambda}{2(\lambda+\mu)}
\end{gathered}
$$

The electrical conductivity of sintered composites was determined at ambient temperature $\left(25^{\circ} \mathrm{C}\right)$ and $40 \mathrm{~V}$ using Hioki 3532 system.

\section{Results and Discussion}

\subsection{Phase composition of prepared powders.}

Figure 1 displays XRD diffraction patterns of $\mathrm{Al}-\mathrm{SiC}$ mixed powders with various $\mathrm{SiC}$ weight percent, i.e., $0,2,4,6$, and $8 \mathrm{wt} . \%$, after milling for $10 \mathrm{~h}$. The patterns indicate the 
existence of two phases, $\mathrm{Al}$ and $\mathrm{SiC}$ phases, according to the XRD-card numbers 89-4037 and 89-2225, respectively. The characteristic peaks of cubic crystal-structure Al phase appear at $2 \theta$ is equal to $38.47,44.72,65.09$, and $78.01^{\circ}$, while characteristic peaks of rhombohedral crystalstructure $\mathrm{SiC}$ phase are exhibited at $2 \theta$ being equal to 35.6 and $60.13^{\circ}$. Its peak intensity increases with increasing its added amount. For the Al-SiC composite, which contains only 2 wt.\% $\mathrm{SiC}$, only one phase (Al phase) is detected because the quantity of $\mathrm{SiC}$ is small enough to be not detected by the XRD device. These results agree with those reported in Ref. [31]. On the other side, with increasing the amount of added $\mathrm{SiC}$ particles, its peaks start to appear in the patterns. All Al peaks are broad with low intensities indicating the higher lattice-strain and dislocation density while lower crystallite sizes [1,8,23]. Figure 2 exhibits the crystallite size, lattice strain, and dislocation density for $\mathrm{Al}-\mathrm{SiC}$ composite powders having different $\mathrm{SiC}$ contents. It is observed from the figure that the crystallite size of $\mathrm{Al}$ reduces with increasing the weight percentages of $\mathrm{SiC}$, while the lattice strain and dislocation density are increased. These results are related to the presence of hard SiC particles, which increase the refinement of $\mathrm{Al}$ grains and their diffusion activation energy [1,32,33]. The values of crystallite sizes of Al-SiC powders that contain 0, 2, 4, 6 and 8 wt.\% $\mathrm{SiC}$ are 33.25, 31.15, 26.22, 21.48 and 18.60 $\mathrm{nm}$, respectively, while the dislocation density are $9.05 \times 10^{-4}, 1.03 \times 10^{-3}, 1.45 \times 10^{-3}, 2.17 \mathrm{x}$ $10^{-3}$ and $2.98 \times 10^{-3} \%$, respectively.

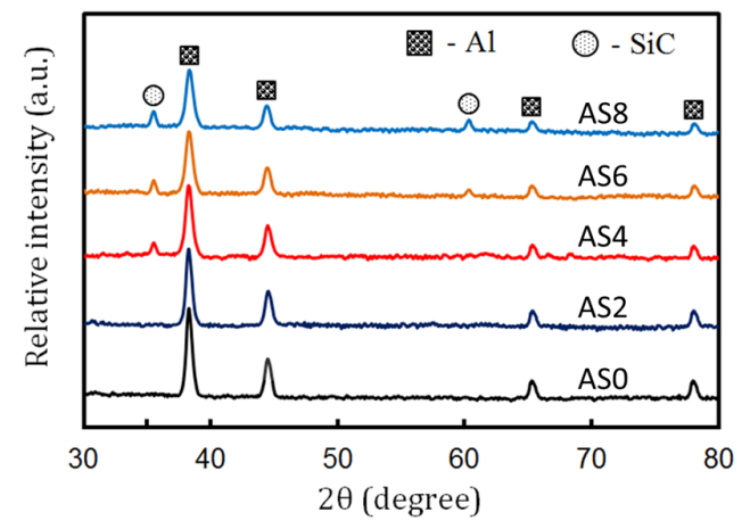

Figure 1. XRD patterns of Al-SiC powders having various $\mathrm{SiC}$ contents after milling for 20h.

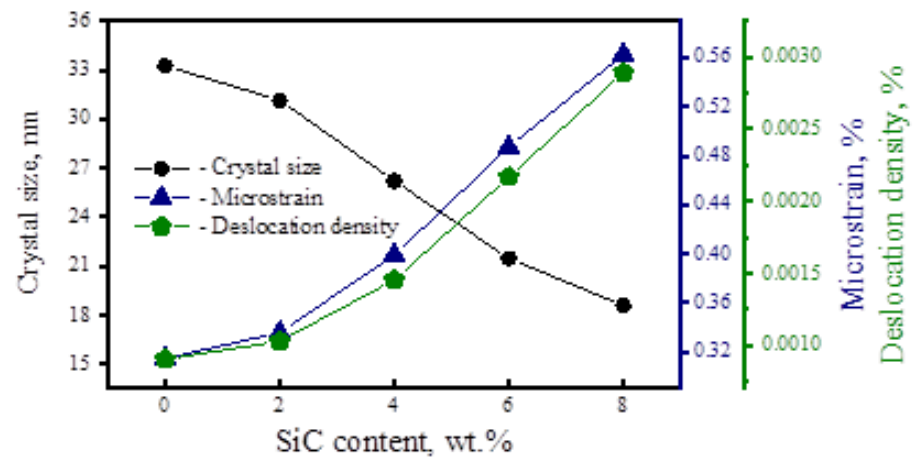

Figure 2. Crystal size, lattice strain, and dislocation density of Al-SiC milled powders with various SiC contents.

\subsection{Particle features of prepared powders.}

Figure 3 displays TEM images of $\mathrm{Al}-\mathrm{SiC}$ nanopowders that contain different percentages of $\mathrm{SiC}$, i.e., 0.0, 2, 4, 6, and $8 \mathrm{wt} . \%$, after milling for $10 \mathrm{~h}$. While the particle size of milled powers as calculated from TEM image analysis is shown in Figure 4. It is exhibited from the figure that the particles are agglomerated in the case of lower amounts of added $\mathrm{SiC}$ and well dispersed after adding higher amounts of SiC. All particles have undefined and 
deformed shapes. Their sizes decrease with the increase of $\mathrm{SiC}$ added amounts. This is due to the higher hardness of $\mathrm{SiC}$ particles in comparison with that of $\mathrm{Al}$ particles. Throughout the mechanical-alloying process, the $\mathrm{Al}$ particles suffer flatting and welding while $\mathrm{SiC}$ particles tend to fragment. The pure $\mathrm{Al}$ sample (un-reinforced with $\mathrm{SiC}$ ) undergoes welding with a higher agglomeration of particles due to their strong plastic deformation [8,34]. This phenomenon appears in TEM images of pure $\mathrm{Al}$ or those having lower amounts of SiC. After increasing the percentages of added SiC particles with their uniform distribution, Al particles' flatting process is weakened, while the fracture of particles is increased. Subsequently, a reduction in particle size is occurred [1]. This means that the particle size decreases with increasing $\mathrm{SiC}$ contents until rich to $39.5 \mathrm{~nm}$ for the sample that contains $8 \mathrm{wt}$. \% $\mathrm{SiC}$.

\subsection{Density and porosity of sintered composites.}

The relative density and apparent porosity of Al-SiC composites in relationship with $\mathrm{SiC}$ contents and sintering temperatures (i.e., 400, 500, and $570^{\circ} \mathrm{C}$ ) are shown in Figure 5.
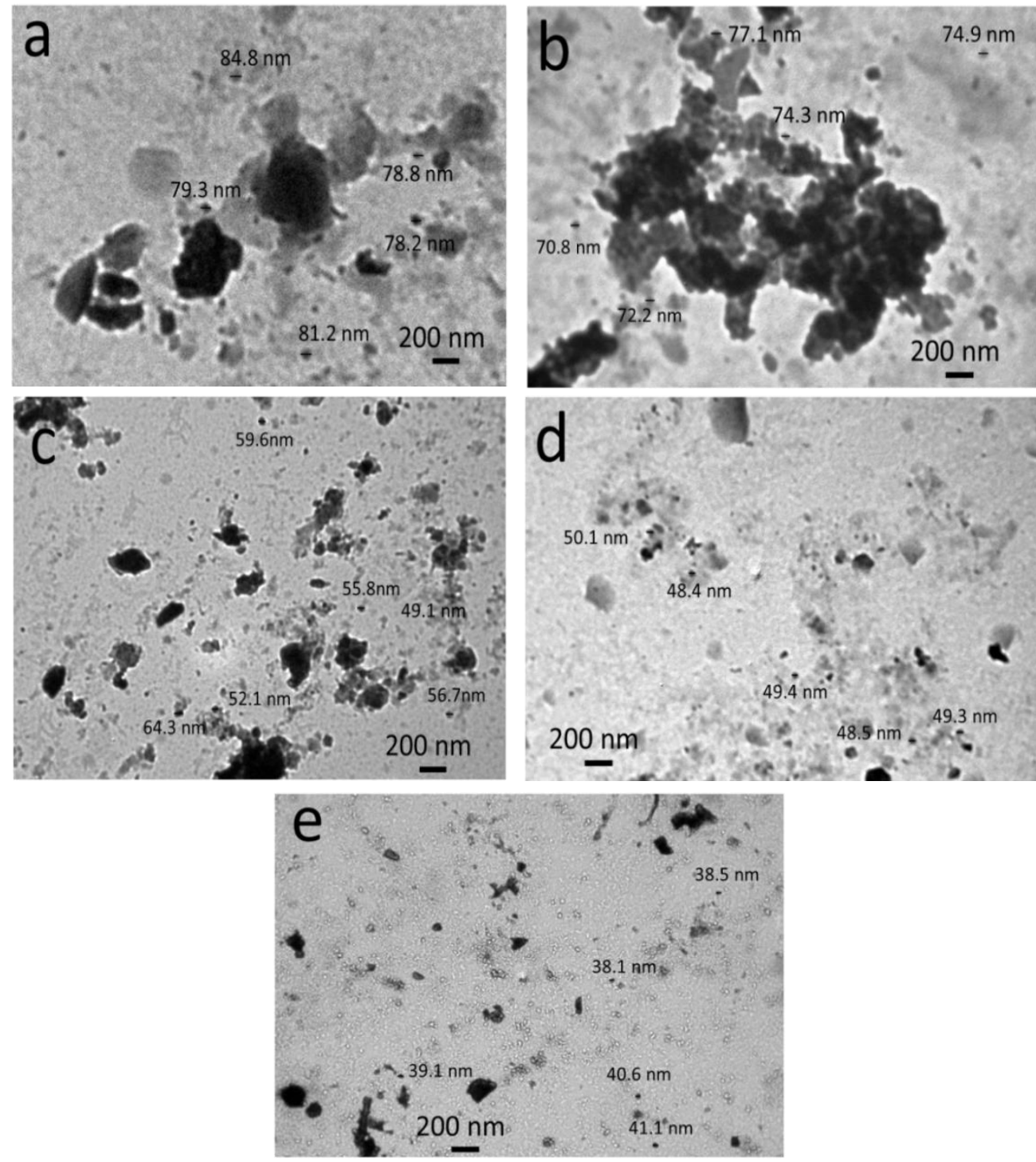

Figure 3. TEM images of Al-SiC milled powders having various $\mathrm{SiC}$ contents; (a) 0.00; (b) 2.0; (c) 4.0; (d) 6.0; (e) $10 \mathrm{wt} . \% \mathrm{SiC}$.

It is worth mentioning that the calculated theoretical density of Al-SiC composites that contain $0.0,2,4,6$, and 8 wt.-\% SiC are 2.700, 2.709, 2.717, 2.726, and $2.735 \mathrm{~g} / \mathrm{cm}^{3}$, 
respectively. The relative density (Figure 5a) of sintered composites drops with raising the $\mathrm{SiC}$ content, while it rises with the increase of firing temperature. On the other hand, the apparentporosity (Figure $5 \mathrm{~b}$ ) rises with rising $\mathrm{SiC}$ content and reduces with rising firing temperature (i.e., opposite trend of relative density). The decreasing relative density with a higher added quantity of $\mathrm{SiC}$ is due to the reduction of densification rate since the $\mathrm{SiC}$ grains are considered a barrier throughout the diffusion stage of sintering and weaken the bonds between Al matrix particles interfacial interaction [9]. Moreover, due to the rising of $\mathrm{SiC}$ content, the boundaries between $\mathrm{Al} / \mathrm{SiC}$ phases increase, improving pore-nucleation and inhibiting the wettability at the interfaces among the grains [35].

Similarly, some results have been published by researchers in the refs $[8,21,23]$. They found that with increasing the amounts of added $\mathrm{ZrO}_{2}$ and $\mathrm{SiC}$ particles incorporated into Almatrix composites, the relative density was decreased while the apparent porosity was decreased. It also indicated from the presented data that the relative density increases with higher firing temperature, while the apparent porosity reduces with increasing sintering temperature. The relative density of specimens sintered at $400 \& 570^{\circ} \mathrm{C}$ decreased from 89.5 to $83.3 \%$ and 96.2 to $92.6 \%$, respectively, increasing $\mathrm{SiC}$ contents from 0 to $8 \mathrm{wt} \%$. The improving of relative density at higher firing temperature is related to the lower melting point of $\mathrm{Al}$ (it is about $660^{\circ} \mathrm{C}$ ) and related to the increasing of diffusion rate with increasing the activation energy required for sintering mechanism to precede neck growth which causes graingrain interaction [36-38].

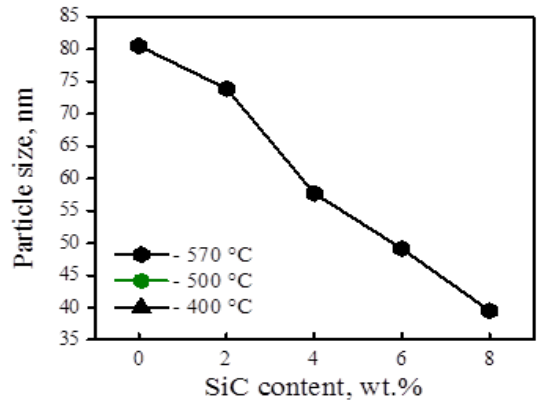

Figure 4. Particle size of milled powders as a function of $\mathrm{SiC}$ percentages.
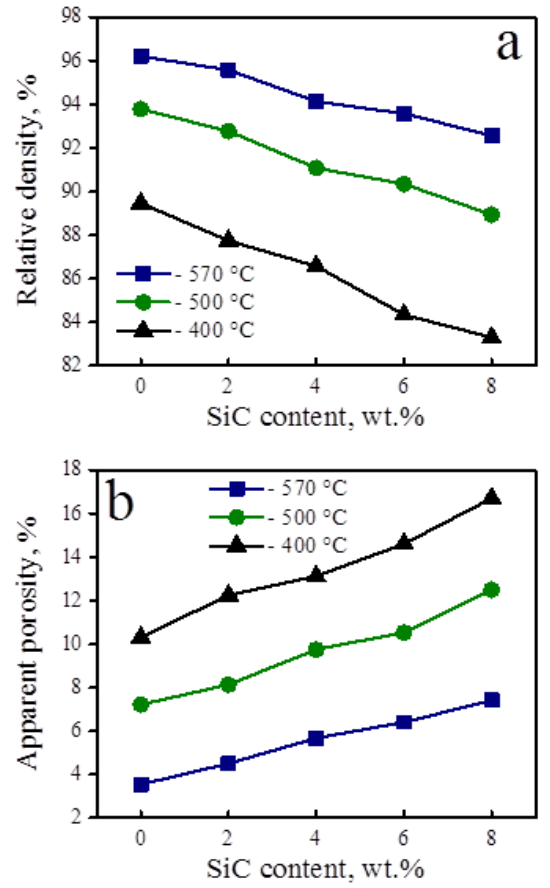

Figure 5. (a) Relative-density; (b) apparent-porosity of Al-SiC composites fired at 400, 500, and $570^{\circ} \mathrm{C}$. 


\subsection{SEM features of sintered specimens.}

Figure 6 shows SEM micrographs of Al-SiC specimens that contain 0.00, 2 \& 8wt.- $\%$ $\mathrm{SiC}$, sintered at $570^{\circ} \mathrm{C}$ for $1 \mathrm{~h}$. Due to the milling of starting powders for $10 \mathrm{~h}$, nanopowders are successfully formed, and $\mathrm{SiC}$ particles are well embedded in the Al-matrix and wetting the $\mathrm{Al}$ particles. Consequently, the homogenous and dense microstructure is obtained with welldispersed $\mathrm{SiC}$ grains. Due to the small size of starting powders and low sintering temperature $\left(570^{\circ} \mathrm{C}\right)$, the grain size of obtained microstructure is very small and seems to be like gel. This means that the grain growth rate is very low even after sintering at $570^{\circ} \mathrm{C}$. As indicated from the microstructure, the number and size of pores rise with the rising of added SiC quantities. This good microstructure will be reflected in the mechanical properties.
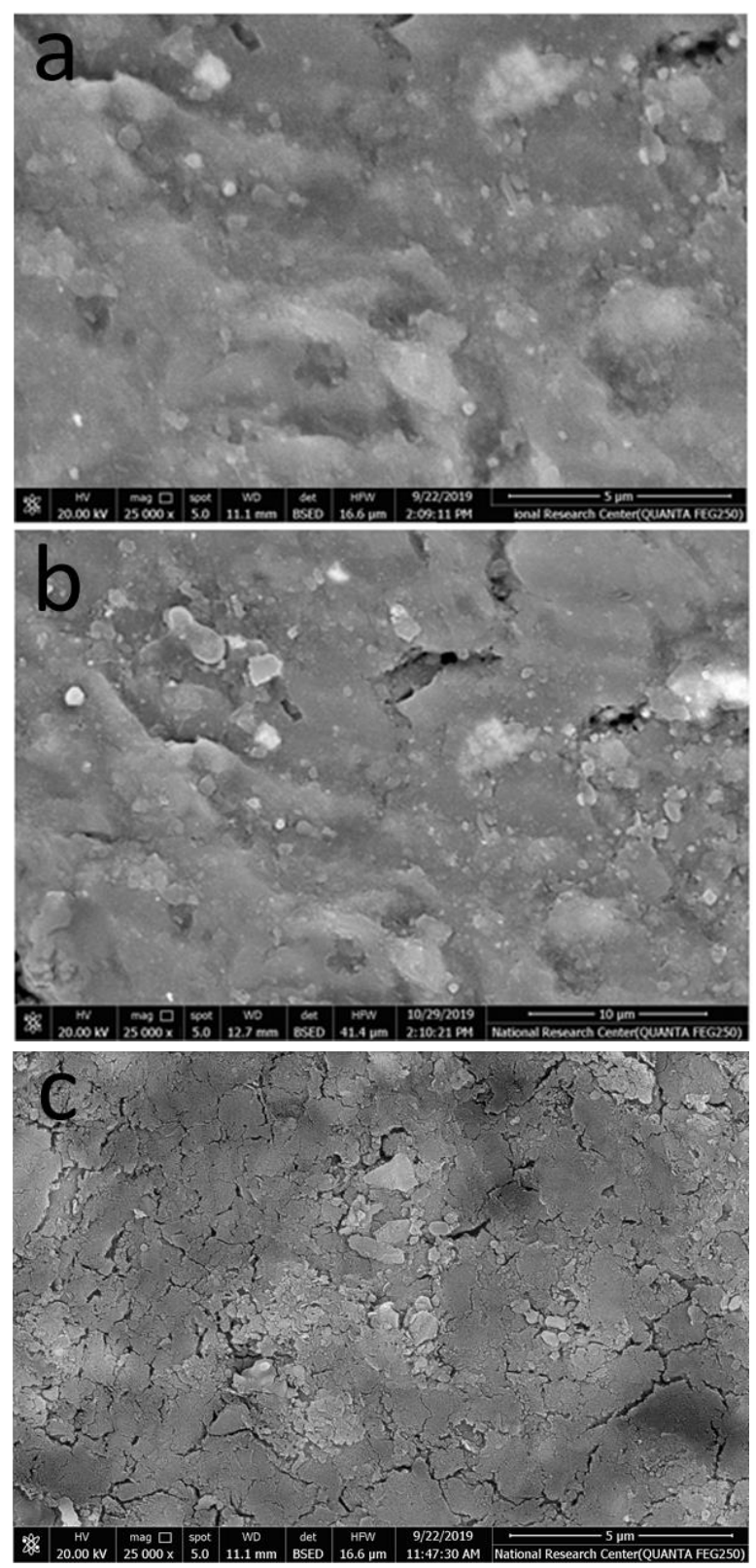

Figure 6. SEM images of $\mathrm{Al}, \mathrm{Al}-4 \mathrm{wt} . \% \mathrm{SiC}$ and $\mathrm{Al}-8 \mathrm{wt} . \% \mathrm{SiC}$ composites sintered at $570{ }^{\circ} \mathrm{C}$.

\subsection{Mechanical characteristics of sintered composites.}

Figure 7 shows the effect of $\mathrm{SiC}$ content and sintering temperature on the microhardness of prepared composites. It can be seen that the microhardness of composites increases with 
increasing both $\mathrm{SiC}$ percent and sintering temperature. After sintering at $400^{\circ} \mathrm{C}$, the microhardness values for $\mathrm{Al}-\mathrm{SiC}$ composites containing 0.0, 2, 4, 6, and $8 \mathrm{wt}$. \% SiC are 279.2, $338.8,429.8,611.2$, and $701.5 \mathrm{MPa}$, respectively. With increasing the sintering temperature to 500 and $570{ }^{\circ} \mathrm{C}$, the microhardness exhibits further increase. The microhardness values for composites reinforced with $8 \mathrm{wt} . \% \mathrm{SiC}$ are 820.1 and $885.4 \mathrm{MPa}$, respectively.

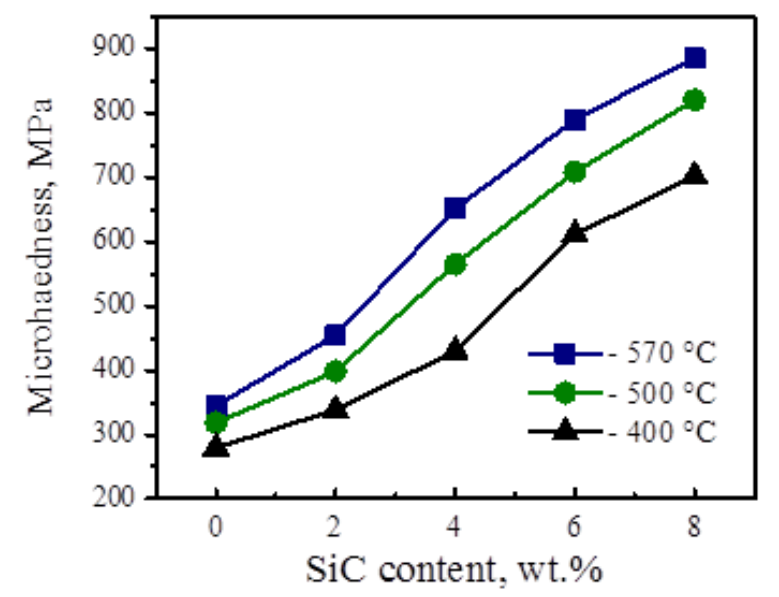

Figure 7. Microhardness of $\mathrm{Al}-\mathrm{SiC}$ composites versus $\mathrm{SiC}$ content and sintering temperature.

The increase of hardness with increasing of $\mathrm{SiC}$ content is due to the greater hardness of $\mathrm{SiC}$ in comparison with that of $\mathrm{Al}$ metal, while the increase of hardness with increasing the sintering temperature is due to the lower porosity of sintered composites at higher temperatures. Figure 8 shows the compressive stress-strain curves of $\mathrm{Al}-\mathrm{SiC}$ composites-specimens having different percentages of $\mathrm{SiC}$ and sintered at 400,500 , and $570^{\circ} \mathrm{C}$ for $1 \mathrm{~h}$. It is indicated that the presence of $\mathrm{SiC}$ increases the load stress and decreases the deformation of the composite. The values of strain decrease with increasing $\mathrm{SiC}$ content; the lowest values were obtained for the composites that contain $8 \mathrm{wt} . \% \mathrm{SiC}$ sintered at different temperatures. Also, the stress of composites increases with increasing sintering temperature, while the deformation of composites decreases with increasing sintering temperature. This means that the presence of hard $\mathrm{SiC}$ in the matrix of the composites improves their load-bearing. On the other hand, the effect of SiC contents and sintering temperatures on compressive strength, yield strength, and fracture strain are shown in Figure 9. It can be seen that compressive strength and yield strength are improved with the rising of $\mathrm{SiC}$ amounts and firing temperature, while the fracture strain is reduced with higher $\mathrm{SiC}$ content and increases with the rising of firing temperature. The values of compressive strength for pure $\mathrm{Al}$ sintered at 400,500 , and $570{ }^{\circ} \mathrm{C}$, are $136.3,181.3$, 187.4 $\mathrm{MPa}$, while for the composite that contains $8 \mathrm{wt} \% \mathrm{SiC}$ sintered at the same sintering temperatures are 240.2, 261.3, 276.2 MPa, respectively. This means that the existence of $8 \mathrm{wt} . \%$ $\mathrm{SiC}$ improves compressive strength values by about $47.5 \%$ compared to their original values of pure Al. Figure 10 shows the strengthening factor $(\mathrm{R})$ of the reinforcement for the sintered composites as a function of $\mathrm{SiC}$ contents and sintering temperatures. The $\mathrm{R}$ values of metalmatrix composites could be calculated by the following equation [39]:

$$
\mathrm{R}=\frac{\sigma_{\mathrm{c}}-\sigma_{\mathrm{m}}}{\mathrm{V} \sigma_{m}}
$$

where $\sigma_{\mathrm{m}}$ is the strength of the matrix, $\sigma_{\mathrm{c}}$ is the strength of metal matrix composite, while $\mathrm{V}$ is the volume-percent of $\mathrm{SiC}$ (reinforcement). The strengthening factor indicates the efficiency of strength enhancement due to reinforcement embedding in the matrix. The figure shows that the values of $\mathrm{R}$ increase with increasing the percentages of added $\mathrm{SiC}$ and sintering temperature. The values of $\mathrm{R}$ for the composites $\mathrm{Al}-2 \mathrm{wt} . \% \mathrm{SiC}$ and $\mathrm{Al}-8 \mathrm{wt}$.\% SiC sintered at 
$570^{\circ} \mathrm{C}$ are 7.64 and 10.11 , respectively. These results are comparable with all aforementioned mechanical properties.
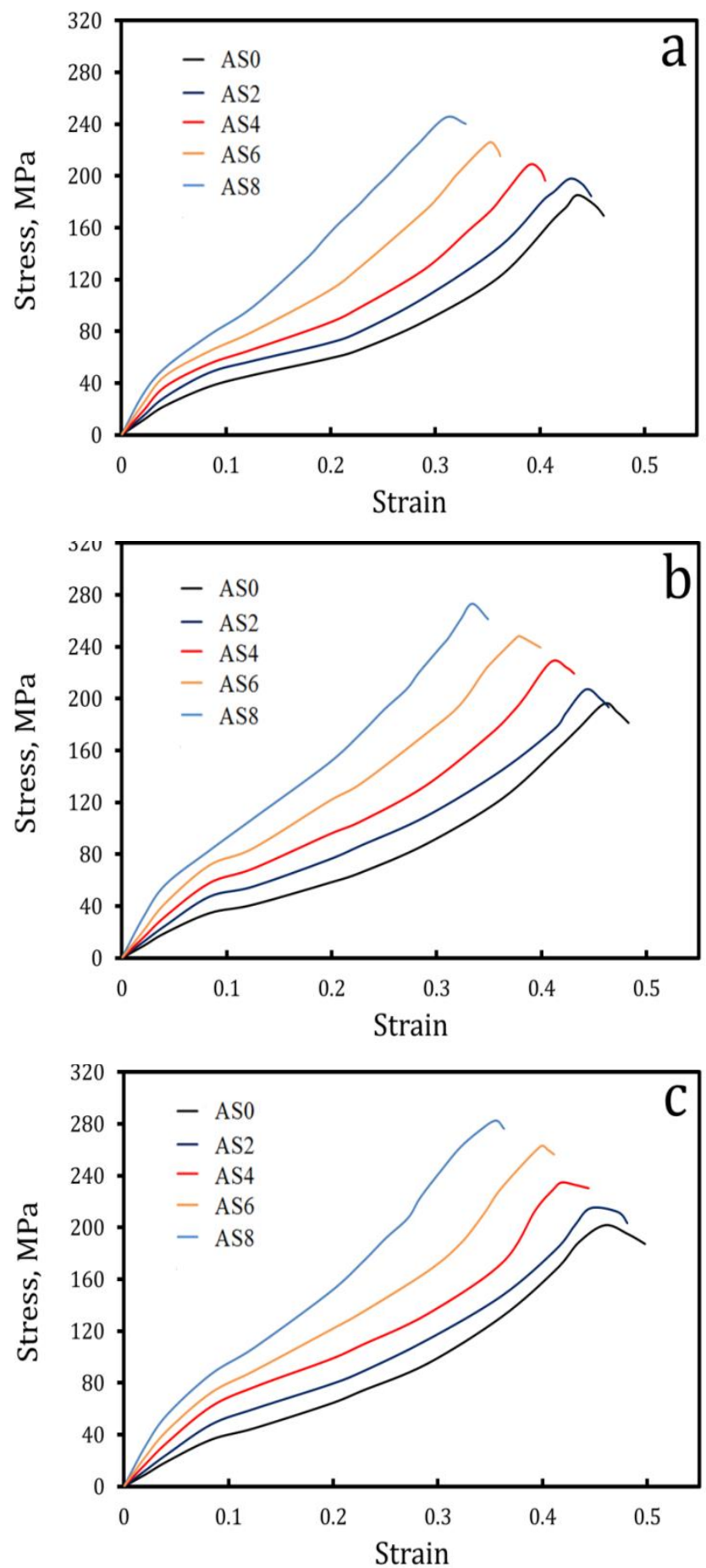

Figure 8. Stress-strain curves of Al-SiC composites that contain $0,2,4,6$, and 8 wt. \% $\mathrm{SiC}$ and sintered at (a) $400^{\circ}$; (b) $500^{\circ}$; (c) $870^{\circ} \mathrm{C}$.

The elastic-moduli values (i.e., E, L, B, G \& v) of all sintered composites in relationship with $\mathrm{SiC}$ contents and sintering temperatures are shown in Figure 11. As seen in the figure, the values of elastic-moduli are enhanced with the rising of $\mathrm{SiC}$ percent and firing temperature (same trend of microhardness and strength). For pure $\mathrm{Al}$ samples fired at $400{ }^{\circ} \mathrm{C}$, the bulkmodulus (B) and Poisson's-ratio (v) are $41.6 \mathrm{GPa}$ and 0.3033 ; they are increased into $84.8 \mathrm{GPa}$ $\& 0.3199$, respectively, when the $\mathrm{SiC}$ percent reaches $8 \mathrm{wt} . \%$. When the sintering temperature increases to 500 and $570{ }^{\circ} \mathrm{C}$, the composite containing $8 \mathrm{wt}$. \% SiC exhibits a bulk modulus of 
116.7 and $135.9 \mathrm{GPa}$, respectively, and Poisson's ratio of 0.3254 and 0.3304 , respectively. The obtained results are similar to those reported in many works of literature [32, 40-42].
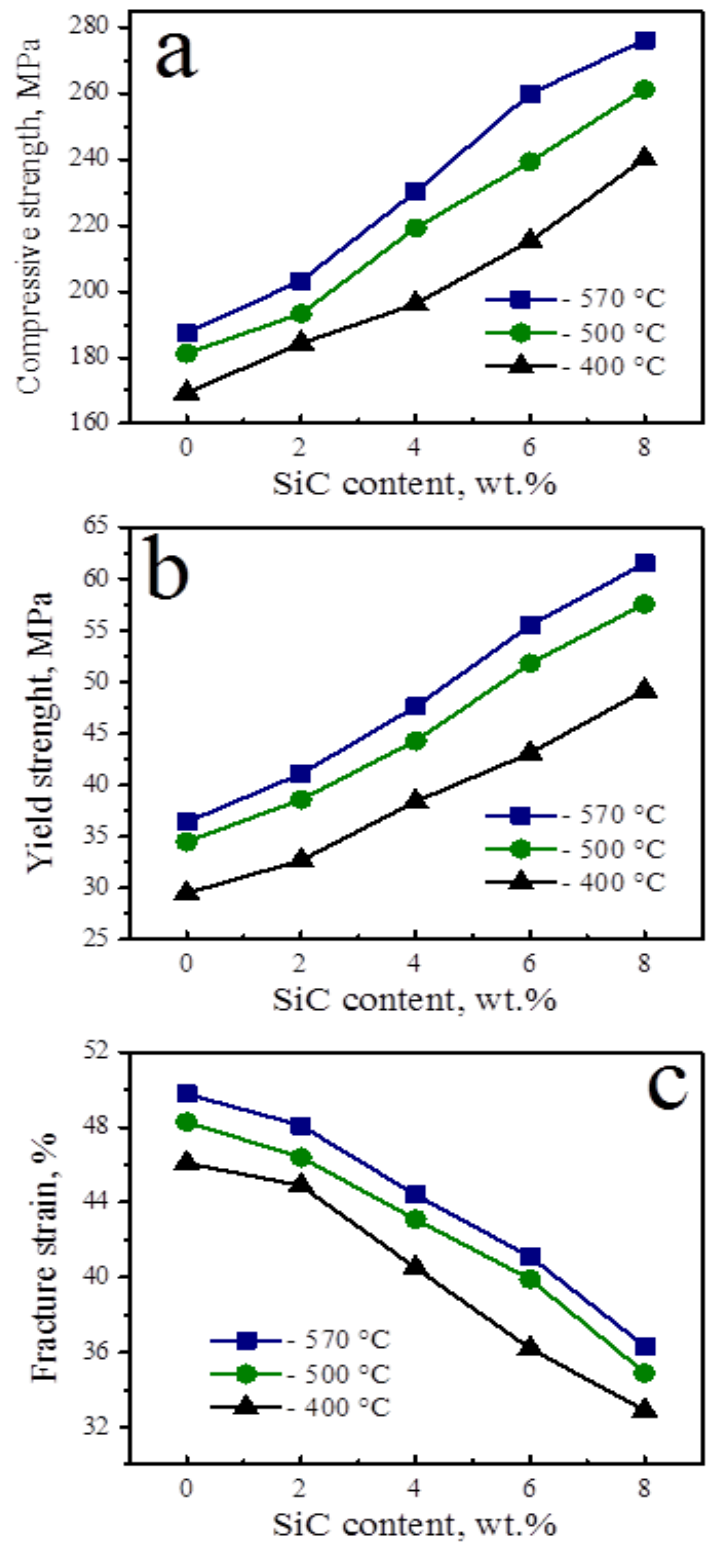

Figure 9. Effect of SiC quantity on compressive-strength, yield-strength, and fracture-strain of composites fired at different sintering temperatures.

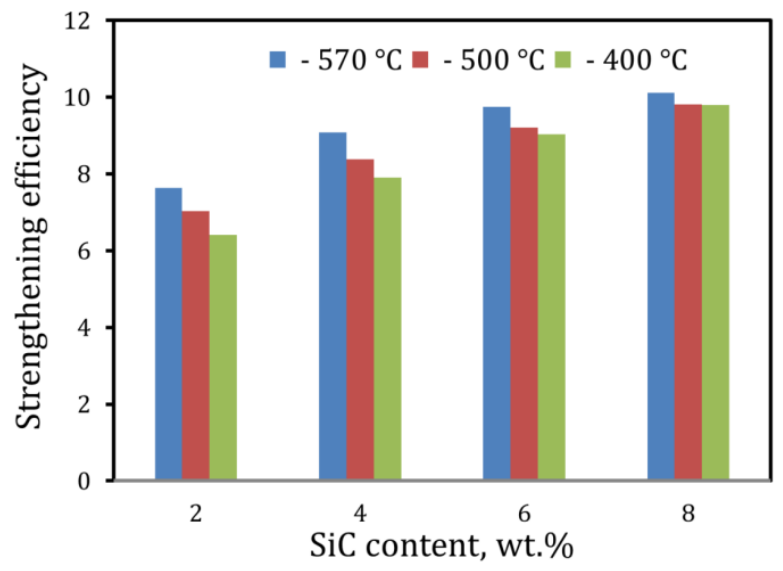

Figure 10. Strengthening factor of reinforcement for sintered composites as a function of $\mathrm{SiC}$ contents and sintering temperatures. 

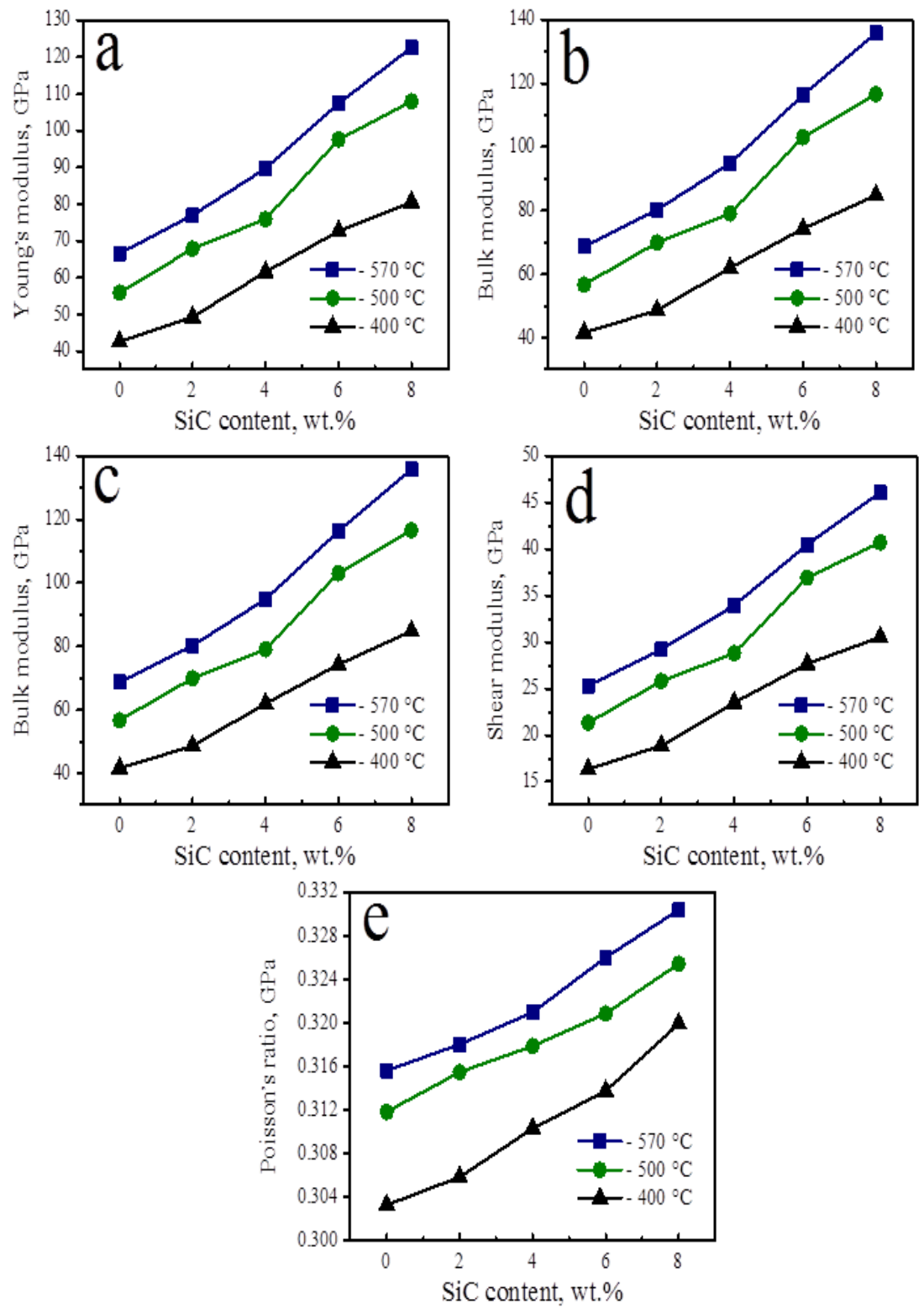

Figure 11. Effect of SiC content on: (a) Young's-modulus; (b) longitudinal modulus; (c) bulk-modulus; (d) shear-modulus; (e) Poisson's-ratio, of Al-SiC composites fired at various temperatures.

Generally, the improvement of mechanical properties (as microhardness, strength, and elastic-moduli) of $\mathrm{Al}-\mathrm{SiC}$ specimens with the increase of $\mathrm{SiC}$ amount is attributed to several reasons. Firstly, the excellent interface and good dispersion between $\mathrm{Al}$ matrix and $\mathrm{SiC}$ reinforcement formed during mechanical milling are effective factors [43]. Secondary, increasing the percentage of hard SiC particles compared to Al raises the development of dislocations, which is considered a barrier for plastic deformation, thus increasing nanocomposites' mechanical properties [44,45]. Gautam et al. [46] reported that the improvement of the strength for AA5052 matrix reinforced with $\mathrm{ZrB}_{2}$ is attributed to refining grains that obstruct the cracks' transmission and growth. The elongation of Al-SiC composites is decreased owing to the presence of nano-SiC reinforcement. The applied load transfers from the Al-matrix into $\mathrm{SiC}$ particles which raise the resistance to plastic-deformation of specimens. Also, there is a thermal expansion mismatch between the $\mathrm{Al}$ matrix (higher thermal expansion coefficient) and the $\mathrm{SiC}$ grains (lower thermal expansion coefficient). This thermal expansion mismatch causes thermal stress in the specimens and dislocates at the interface $[47,48]$. Increasing the sintering temperature of the composites also has a positive effect on overall 
mechanical properties due to increasing the interaction between the grains and decreasing the porosity. Similar results about the influence of firing temperature on mechanical characteristics of metal-matrix composites have been reported by several researchers using different reinforcements $[1,2,23,49,50]$.

\subsection{Electric properties of sintered composites.}

Figure 12 shows the electrical conductivity of Al-SiC composites that include $0.0,2,4$, 6, and $8 \mathrm{wt} . \% \mathrm{SiC}$ and sintered at different temperatures. The results in Figure 12 exhibit that the conductivity of sintered composites decreases slightly with increasing SiC contents and increases remarkably with firing temperature. The conductivity of the composites fired at $400^{\circ} \mathrm{C}$ reduces from $3.41 \times 10^{7}$ to $2.62 \times 10^{7} \mathrm{~S} / \mathrm{m}$ when the $\mathrm{SiC}$ content increases from 0.0 to 8 wt. $\%$, while it increases with increasing sintering temperature to 500 and $570{ }^{\circ} \mathrm{C}$.

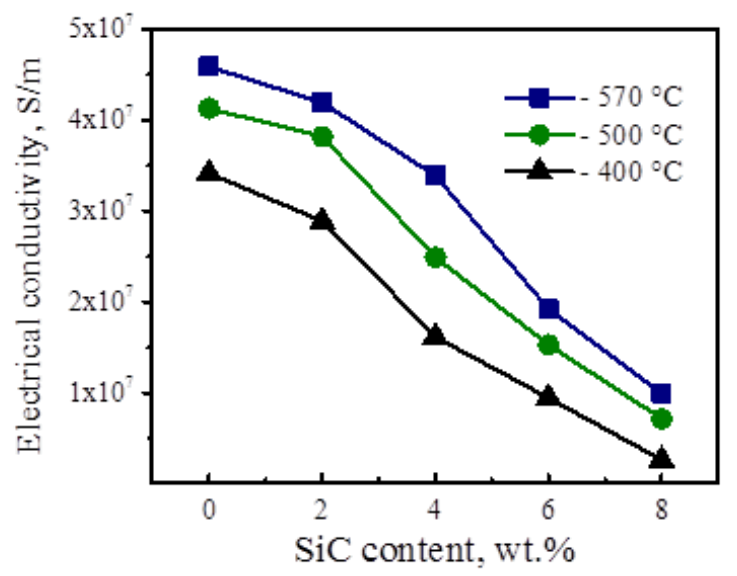

Figure 12. Electrical conductivity of Al-SiC composites sintered at different sintering temperatures.

The conductivity decreases from $4.13 \times 10^{7}$ to $7.15 \times 10^{6} \mathrm{~S} / \mathrm{m}$ and from $4.58 \times 10^{7}$ to $9.9 \times 10^{6} \mathrm{~S} / \mathrm{m}$, respectively. These results are related to the fact that the conductivity of ceramic $\mathrm{SiC}$ reinforcement is less than the conductivity of the Al matrix. Therefore, when the content of added $\mathrm{SiC}$ particles increases in the $\mathrm{Al}$ matrix, this leads to decreasing the conductivity of the composites [1,23,51]. Moreover, in Al-metal, the electrons-nucleus interaction is low, so the movement of electrons is easy and results in high conductivity. After adding SiC to the $\mathrm{Al}$ matrix, this causing stable bonds between the electrons and nucleus, leading to decreasing the conductivity [52-54]. The increasing electrical conductivity of fired composites with the increase of firing temperature might decrease the porosity and improve the density $[23,55,56]$.

\section{Conclusions}

Al-SiC nanopowders having different SiC percentages (i.e., 0.0, 2, 4, 6, 8 wt.\%) have been successfully prepared by the mechanical alloying method and fired in an inert atmosphere at various firing temperatures, i.e., 400,500 , and $570^{\circ} \mathrm{C}$. The crystallite and particle sizes of milled powders were decreased with increasing SiC contents; their values were $18 \mathrm{~nm}$ and $39,5 \mathrm{~nm}$, respectively, when the value of $\mathrm{SiC}$ reached $8 \mathrm{wt} . \%$. SEM analysis showed that the $\mathrm{SiC}$ particles were distributed homogeneously in the $\mathrm{Al}$ matrix, indicating a good bonding between the $\mathrm{SiC}$ and $\mathrm{Al}$ matrix. The relative density of fired composites was decreased with increasing $\mathrm{SiC}$ content, while it increased with the increase of firing temperature. The rising of $\mathrm{SiC}$ content and sintering temperature caused improving the mechanical properties, especially the fracture strain. The microhardness, compressive strength, strengthening factor, and elastic 
modulus of the Al-8wt.\% SiC composite sintered at $570{ }^{\circ} \mathrm{C}$ were $885.4 \mathrm{MPa}, 276.2 \mathrm{MPa}, 10.11$, and $182 \mathrm{GPa}$, respectively. Furthermore, the electrical conductivity of fired composites was also decreased with increasing $\mathrm{SiC}$ percentages and improved with the increase of firing temperature.

\section{Funding}

This research received no external funding.

\section{Acknowledgments}

Not applicable.

\section{Conflicts of Interest}

The authors declare no conflict of interest.

\section{References}

1. Zawrah, M. F.; Mostafa, H.; Taha, M. A. Effect of SiC content on microstructure, mechanical and electrical properties of sintered $\mathrm{Al}-20 \mathrm{Si}-\mathrm{xSiC}$ nanocomposites fabricated by mechanical alloying. Mater. Res. Express 2019, 6, 12501, https://doi.org/10.1088/2053-1591/ab534e.

2. Moustafa, E. B.; Abu Shanab, W.S.; Ghandourah, E.; Taha, M.A. Microstructural, mechanical and thermal properties evaluation of $\mathrm{AA} 6061 / \mathrm{Al}_{2} \mathrm{O}_{3}-\mathrm{BN}$ hybrid and mono nanocomposite surface. JMRT 2020, 6, 1548615495, https://doi.org/10.1016/j.jmrt.2020.11.010.

3. Carreño-Gallardo, C.; Estrada-Guel, I.; López-Meléndez, C.; Ledezma-Sillas, E.; Castañeda-Balderas, R.; Pérez-Bustamante, R.; Herrera-Ramírez, J.M. B 4 C particles reinforced Al2024 composites via mechanical milling. Metals 2018, 8, 1-10, https://doi.org/10.3390/met8080647.

4. Moustafa, E. B.; Mosleh, A.O. Effect of (Ti-B) modifier elements and FSP on 5052 aluminum alloy. J. Alloy. Compds. 2020, 825, 153745, https://doi.org/10.1016/j.jallcom.2020.153745.

5. Ali, S. M. The effect of reinforced SiC on the mechanical properties of the fabricated hypoeutectic Al-Si alloy by centrifugal casting. Eng. Sci. Technol. Int J. 2019, 22, 1125-1135, https://doi.org/10.1016/j.jestch.2019.02.009.

6. Zhang, P.X.; Yan, H.; Liu, W.; Zou, X.L.; Tang, B.B. Effect of T6 Heat Treatment on Microstructure and Hardness of Nanosized $\mathrm{Al}_{2} \mathrm{O}_{3}$ Reinforced 7075 Aluminum Matrix Composites. Metals 2019, 9, 1-12, https://doi.org/10.3390/met9010044.

7. Moustafa, E. Effect of Multi-pass friction stir processing on mechanical properties for $\mathrm{AA} 2024 / \mathrm{Al}_{2} \mathrm{O}_{3}$ nanocomposites, Materials 2017, 11, 1-17, https://doi.org/10.3390/ma10091053.

8. Taha, M. A.; Elkomy G.M., Abo Mostafa, H.; El Said Gouda. Effect of $\mathrm{ZrO} 2$ contents and ageing times on mechanical and electrical properties of Al-4.5 wt.\% $\mathrm{Cu}$ nanocomposites prepared by mechanical alloying. Mater. Chem. Phys. 2018, 206, 116-123, https://doi.org/10.1016/j.matchemphys.2017.11.058.

9. Ağaoğulları, D. Effects of $\mathrm{ZrC}$ content and mechanical alloying on the microstructural and mechanical properties of hypoeutectic Al-7 wt.\% Si composites prepared by spark plasma sintering. Ceram. Int. 2019, 45, 13257-13268, https://doi.org/10.1016/j.ceramint.2019.04.013.

10. ALweendo, S.T.; Johnson, O.T.; Shongwe, B.M.; Kavishe, F.P.; Borode. J.O. Microstructural and Mechanical Properties of Alumina $\left(\mathrm{Al}_{2} \mathrm{O}_{3}\right)$ Matrix Composites Reinforced with SiC from Rice Husk by Spark Plasma Sintering. Mat. Res. 2020, 23, https://doi.org/10.1590/1980-5373-mr-2019-0363.

11. Carreño-Gallardo, C.; Estrada-Guel, I; López-Meléndez, C.; Ledezma-Sillas, E.; Castañeda-Balderas, R.; Pérez-Bustamante, R.; Herrera-Ramírez, J.M. B 4 C particles reinforced Al2024 composites via mechanical milling, Metals 2018, 8, 1-10, https://doi.org/10.3390/met8080647.

12. Taha, M.A.; Nassar, A.H., Zawrah, M.F. In-situ formation of composite having hard outer layer based onaluminum dross reinforced by $\mathrm{SiC}$ and $\mathrm{TiO}_{2}$. Constr. Build. Mater. 2020, 248, 118638, https://doi.org/10.1016/j.conbuildmat.2020.118638. 
13. Akbarpoura, M.R.; Mirabada, H. M.; Alipour, S. Microstructural and mechanical characteristics of hybrid $\mathrm{SiC} / \mathrm{Cu}$ composites with nano- and micro-sized SiC particles. Ceram. Int. 2019, 45, 3276-3283, https://doi.org/10.1016/j.ceramint.2018.10.235.

14. Liu, P.; Wang, A.Q.; Xie, J.P.; Hao, S.M. Effect of heat treatment on microstructure and mechanical properties of SiCp/2024 aluminum matrix composite. J. Wuhan Univ. Technol. 2015, 30, 1229-1233, https://doi.org/10.1007/s11595-015-1300-9.

15. Ashok, N.; Palanisamy, S. Effect of particles size on the mechanical properties of SiC-reinforced aluminum 8011 composites. Mater. Tehnol. 2017, 4, 667-672, https://doi.org/10.17222/mit.2016.252.

16. El-Galy, I. M.; Ahmed, M.H.; Bassiouny, B. I. Characterization of functionally graded Al-SiCp metal matrix composites manufactured by centrifugal casting. Alexandria Engineering Journal 2017, 56, 371-381, https://doi.org/10.1016/j.aej.2017.03.009.

17. Yang, Z; Leon, L.; Shaw; Zawrah ,M.F.; Misael, M. Synthesis of Silicon Carbide Nanopowder using Silica Fume. J. Am. Ceram. Soc. 2010, 93, 3159-3167, https://doi.org/10.1111/j.1551-2916.2010.03867.x.

18. Taha, M.A.; Youness, R.A.; Zawrah, M.F. Review on nanocomposites fabricated by mechanical alloying. Int. J. Min. Met. Mater. 2019, 26, 1047-1058, https://doi.org/10.1007/s12613-019-1827-4.

19. Taha, M.A.; Nassar, A.H.; Zawrah, M.F. Improvement of wettability sinterability mechanical and electrical properties of $\mathrm{Al}_{2} \mathrm{O}_{3}$-Ni nanocomposites prepared by mechanical alloying. Ceram. Int. 2017, 43, 3576-3582, https://doi.org/10.1016/j.ceramint.2016.11.194.

20. Madeja, B.L.; Garbiecb D.; Madej M. Effect of sintering temperature on microstructure and selected properties of spark plasma sintered Al-SiC composites. Vacuum 2019, 164, 250-255, https://doi.org/10.1016/j.vacuum.2019.03.033.

21. Zawrah, M. F.; Taha, M.A.; Saadallah, F.; Mostafa, A. G.; Hassan, M.Y.; Nasr, M. Effect of nano-ZrO $\mathrm{Zn}_{2}$ on the properties of $\mathrm{Al}-\mathrm{Al}_{2} \mathrm{O}_{3}$ nanocomposites prepared by mechanical alloying. Silicon 2018, 10, 1523-1531, https://doi.org/10.1007/s12633-017-9635-9.

22. Baig, M.; Ammar, H. R.; Seikh, A.H. Thermo-mechanical responses of nanocrystalline Al-Fe alloy processed using mechanical alloying and high frequency heat induction sintering. Mater. Sci. Eng. A 2016, 655, 132141, https://doi.org/10.1016/j.msea.2015.12.077.

23. Taha, M.A.; Zawrah, M. F. Effect of nano $\mathrm{ZrO}_{2}$ on strengthening and electrical properties of Cu-matrix nanocomposits prepared by mechanical alloying. Ceram. Int. 2017, 43, 12698-12704, https://doi.org/10.1016/j.ceramint.2017.06.153.

24. Zawrah, M. F.; Taha, M.A.; Abo Mostafa, H. In-situ formation of $\mathrm{Al}_{2} \mathrm{O}_{3} / \mathrm{Al}$ core-shell from waste material: Production of porous composite improved by graphene. Ceram. Int. 2018, 44, 10693-10699, https://doi.org/10.1016/j.ceramint.2018.03.101.

25. Zawrah, M.F.; Essawy, R.A.; Zayed, H. A.; Abdel Fattah, A.H.; Taha, M.A. Mechanical alloying, sintering and characterization of $\mathrm{Al}_{2} \mathrm{O}_{3}-20$ wt.\%-Cu nanocomposite. Ceram. Int., 2014, 40, 31-38, https://doi.org/10.1016/j.ceramint.2013.05.099.

26. Zawrah, M.F.; Shaw, L. Microstructure and Hardness of Nanostructured Al-Fe-Cr-Ti Alloys through Mechanical Alloying. Material Science and Engineering A 2003, 355, 37-49, https://doi.org/10.1016/S09215093(03)00058-3.

27. Taha, M.A.; Youness, R.A.; Zawrah, M. F. Phase composition, sinterability and bioactivity of amorphous nano-CaO- $\mathrm{SiO}_{2}-\mathrm{CuO}$ powder synthesized by sol-gel technique. Ceram. Int. 2020, 46, 24462-24471, https://doi.org/10.1016/j.ceramint.2020.06.231.

28. Youness, R.A.; Taha, M.A.; El-Kheshen, A.A.; Ibrahim M. Influence of the addition of carbonated hydroxyapatite and selenium dioxide on mechanical properties and in vitro bioactivity of borosilicate inert glass. Ceram. Int. 2018, 44, 20677-20685, https://doi.org/10.1016/j.ceramint.2018.08.061.

29. Taha, M.A.; Youness, R.A.; El-Bassyouni, G.T.; Azooz, M.A. FTIR Spectral Characterization, Mechanical and Electrical Properties of $\mathrm{P}_{2} \mathrm{O}_{5}-\mathrm{Li}_{2} \mathrm{O}-\mathrm{CuO}$ Glass-Ceramics. Silicon 2020, https://doi.org/10.1007/s12633020-00661-5.

30. Khattab, R.M.; Sadek, H.E.H.; Taha, M.A.; Amira, M.; EL-Rafei. Recycling of silica fume waste in the manufacture of $\beta$-eucryptite ceramics. Mater. Character. 2021, 171, 110740, https://doi.org/10.1016/j.matchar.2020.110740.

31. Du, X.; Zheng, K.; Liu, F. Microstructure and mechanical properties of graphene-reinforced aluminummatrix composites. Mater. Technol. 2018, 6, 763-768, https://doi.org/10.17222/mit.2018.021. 
32. Sulaiman, S.; Marjom, Z.; Ismail, S.; Ariffin, M.K.A.; Ashrafi, N. Effect of modifier on mechanical properties of aluminum silicon carbide (Al-SiC) Composites. Procedia Engineering 2017, 184, 773-777, https://doi.org/10.1016/j.proeng.2017.04.156.

33. Mostaed, E.; Saghafian, H.; Mostaed, A.; Shokuhfar, A.; Rezaie, H.R. Investigation on preparation of Al$4.5 \% \mathrm{Cu} / \mathrm{SiCp}$ nanocomposite powder via mechanical milling. Powder Technol 2012, 221, 278-283, https://doi.org/10.1016/j.powtec.2012.01.012.

34. Taha, M.A.; Nassar, A.H.; Zawrah, M.F. Effect of milling parameters on sinterability, mechanical and electrical properties of $\mathrm{Cu}-4$ wt.\% $\mathrm{ZrO}_{2}$ nanocomposite. Mater. Chem. Phys. 2016, 181, 26-32, https://doi.org/10.1016/j.matchemphys.2016.06.030.

35. Prosviryakov, A.S. SiC content effect on the properties of $\mathrm{Cu}-\mathrm{SiC}$ composites produced by mechanical alloying. Alloys Compd. 2015, 632, 707-710, https://doi.org/10.1016/j.jallcom.2015.01.298.

36. Reddy, S.K.; Kannan, M.; Karthikeyan, R.; Prashanth, S.; Reddy, R.B. A Review on Mechanical and Thermal Properties of Aluminum Metal Matrix Composites. E3S Web of Conferences 2020, 184, 01033, https://doi.org/10.1051/e3sconf/202018401033.

37. Zawrah, M.F.; Zayed, H.A.; Essawy, R.A.; Nassar, A.H.; Taha, M.A. Preparation by mechanical alloying, characterization and sintering of $\mathrm{Cu}-20 \mathrm{wt} \% \mathrm{Al}_{2} \mathrm{O}_{3}$ nanocomposites. Mater. Des. 2013, 46, 485-490, https://doi.org/10.1016/j.matdes.2012.10.032.

38. Zawrah, M.F.; Aly, M.H. In-Situ Formation of $\mathrm{Al}_{2} \mathrm{O}_{3}$-SiC-Mullite from Al-Matrix Composites. Ceram. Int. 2006, 32, 1, 21-28, https://doi.org/10.1016/j.ceramint.2004.12.005.

39. Lakshmi Dasari, B.; Morshed, M.; Nouri, J.M.; Brabazon, D.; Naher, S. Mechanical properties of graphene oxide reinforced aluminum matrix composites. Composites Part B 2018, 145, 136-44, https://doi.org/10.1016/j.compositesb.2018.03.022.

40. Karthikeyan, A.; Nallusamy, S. Investigation on mechanical properties and wear behavior of Al-Si-SiCgraphite composite using SEM and EDAX. Mater. Sci. Eng. 2017, 225, 012281, https://doi.org/10.1088/1757-899X/225/1/012281.

41. Zawrah, M.F.; El Gezary, M. Mechanical properties of SiC ceramics by ultrasonic nondestructive technique and its bioactivity. Mater. Chem. Phys. 2007, 106, 330-307, https://doi.org/10.1016/j.matchemphys.2007.06.010.

42. Mobasherpour, I.; Tofigh, A.A.; Ebrahimi, M. Effect of nano-size $\mathrm{Al}_{2} \mathrm{O}_{3}$ reinforcement on the mechanical behavior of synthesis 7075 aluminum alloy composites by mechanical alloying. Mater. Chem. Phys. 2013, 138, 535-541, https://doi.org/10.1016/j.matchemphys.2012.12.015.

43. Reddya, M.P.; Shakoora, R.A.; Parande, G.; Manakarib, V.; Ubaida, F.; Mohamed, A.M.A.; Gupta, M. Enhanced performance of nano-sized $\mathrm{SiC}$ reinforced Al metal matrix nanocomposites synthesized through microwave sintering and hot extrusion techniques. Pro. Nat. Sci-Mater. 2017, 27, 606-614, https://doi.org/10.1016/j.pnsc.2017.08.015.

44. Almotairy, S.M; Alharthi, N.H.; Alharbi, H.F.; Abdo, H.S. Superior Mechanical performance of inductively Sintered Al/Sic nanocomposites processed by novel Milling Route. Scientific Reports 2020, 10, 10368, https://doi.org/10.1038/s41598-020-67198-w.

45. Khdair, A.I; Fathy, A; Enhanced strength and ductility of Al-SiC nanocomposites synthesized by accumulative roll bonding. J mater res technol. 2020, 9, 478-489, https://doi.org/10.1016/j.jmrt.2019.10.077.

46. Aynalem, G.F. Processing Methods and Mechanical Properties of Aluminum Matrix Composites. Adv. in Mater. Sci. and Eng. 2020, https://doi.org/10.1155/2020/3765791.

47. Prasad, D.S.; Shoba, C.; Ramanaiah, N. Investigations on mechanical properties of aluminium hybrid composites. J. Mater. Res. Technol 2014, 3, 79-85, https://doi.org/10.1016/j.jmrt.2013.11.002.

48. Singh J.; Chauhan A. Characterization of hybrid aluminum matrix composites for advanced applications a review. J. Mater. Res. Technol. 2016, 5, 159-169, https://doi.org/10.1016/j.jmrt.2015.05.004.

49. Hassanein, W.S.; Sadoun, A.M.; Abu-Oqail, A. Effect of SiC addition on the mechanical properties and wearbehavior of Al-SiC nanocomposites produced by accumulative rollbonding. Mater. Res. Express, 2020, 7, 075006, https://doi.org/10.1088/2053-1591/ab9d53.

50. Kır, D.; Islak, S.; Çelik, H.; Çelik, E. Effect of the cBN content and sintering temperature on the transverse rupture strength and hardness of cBN/diamond cutting tools. Sci. Sinter. 2012, 44, 235-243, htps://doi.org/10.2298/SOS1202235K.

51. Malliaris, A.; Turner, T. Influence of particle size on the electrical resistivity of compacted mixtures of polymeric and metallic powders. Appl. Phys. 1971, 42, 614-618, https://doi.org/10.1063/1.1660071. 
52. Aydın, M.; Toker, G.P.; Acar, E.; Karaca, H.E. Processing and compressive response of Al/SiC functionally graded composites. Eur. Phys. J. Plus 2020, 135, 486, https://doi.org/10.1140/epjp/s13360-020-00501-w.

53. Venkateshwar Reddy, P.; Suresh Kumar, G.; Mohana Krishnudu, D.; Raghavendra Rao, H. Mechanical and Wear Performances of Aluminium-Based Metal Matrix Composites: A Review. Journal of Bio- and TriboCorrosion 2020, 6, 83, https://doi.org/10.1007/s40735-020-00379-2.

54. Repeto, D.; Fernández-Vidal, S.R.; Mayuet, P.F.; Salguero, J.; Batista, M. On the Machinability of an Al63\%SiC Metal Matrix Composite. Materials 2020, 13, 1186, https://doi.org/10.3390/ma13051186.

55. Khan, A.; Abdelrazeq, M.W.; Mattli, M.R.; Yusuf, M.M.; Alashraf, A.; Matli, P.R.; Shakoor, R.A. Structural and Mechanical Properties of Al-SiC-ZrO 2 Nanocomposites Fabricated by Microwave Sintering Technique. Crystals 2020, 10, 904, https://doi.org/10.3390/cryst10100904.

56. Yusoff, M.; Hussainm, Z. Effect of sintering parameters on microstructure and properties of mechanically alloyed copper-tungsten carbide composite. Mater. Mech. Manuf. 2013, 1, 283-286, https://doi.org/10.7763/IJMMM.2013.V1.60. 